\title{
Doeltreffende identifikasie van poenskop Bonsmara- en Drakensberger- vleisbeeste met behulp van DNS-tegnologie
}

\author{
Outeurs: \\ Rulien Grobler, \\ C Visser, \\ E van Marle-Köster \\ Affiliasie: \\ Departement Vee- en \\ Wildkunde, Universiteit \\ van Pretoria \\ Privaatsak X20, Pretoria, \\ 0028 \\ Korresponderende outeur: \\ R Grobler \\ E-pos: rulieng@hotmail.com \\ Hoe om hierdie artikel aan \\ te haal: \\ Rulien Grobler, C Visser, \\ E van Marle-Köster, \\ Doeltreffende identifikasie \\ van poenskop Bonsmara- \\ en Drakensberger- \\ vleisbeeste met behulp \\ van DNS-tegnologie, \\ Suid-Afrikaanse Tydskrif \\ vir Natuurwetenskap en \\ Tegnologie 38(1) (2019). \\ https://doi.org/10.36303/ \\ SATNT.2019.38.1.769 \\ Kopiereg: \\ (c) 2019. Authors. \\ Licensee: Die Suid- \\ Afrikaanse Akademie vir \\ Wetenskap en Kuns. \\ Hierdie werk is onder \\ die Creative Commons \\ Attribution License \\ gelisensieer.
}

\begin{abstract}
Efficient identification of polled Bonsmara and Drakensberger beef cattle breeds using DNA technology: The selection for polledness based on phenotypic records is time consuming and ineffective. Breeding genetically polled animals would be a welfare friendly alternative, as well as a long-term solution to dehorning. Using DNA technology to identify polled animals allows for improved selection of the polled trait in a much faster and more efficient way.
\end{abstract}

Beeste wat geneties horingloos is (poenskop), het verskeie voordele, soos dat hulle makliker is om te hanteer en te vervoer, minder spasie in voerkrale benodig en ook dat hulle risiko van beserings, kneusings en potensiële karkasskade minder is, wat derhalwe ekonomiese verliese beperk. Om kalwers te onthoring is 'n pynlike prosedure, met wêreldwye druk vir minder pynlike praktyke. Die seleksie vir poenskopbeeste, gebaseer op fenotipiese rekords, is tydrowend en oneffektief en lei tot stadige genetiese vordering. Die teel van poenskopdiere deur DNS-tegnologie te gebruik, bied 'n welsynsvriendelike alternatief en langtermynoplossing om kalwers te onthoring. Die POLLED-lokus is gekarteer tot BTA1 en minstens twee verskillende allele bestaan by hierdie lokus: die Celtic $\left(\mathrm{P}_{\mathrm{C}}\right)$ en die Friesian- $\left(\mathrm{P}_{\mathrm{F}}\right)$ variante. Die poenageen is outosomaal dominant en indien teenwoordig sal die uitdrukking van die horingfenotipe onderduk word. As gevolg van dominansie kan daar nie tussen die homosigoot- en heterosigoot-poenafenotipe onderskei word nie. Die doel van hierdie studie is om die effektiwiteit van die Celtic-variant $\left(\mathrm{P}_{\mathrm{C}}\right)$ as diagnostiese DNS-toets in Bonsmaraen Drakensberger-vleisbeeste te evalueer. Grobler et al (2018) het reeds bevestig dat die Celtic variant $\left(\mathrm{P}_{\mathrm{C}}\right)$ van die POLLED-lokus verantwoordelik is vir die poenskopfenotipe in Suid-Afrikaanse Bonsmara- en Drakensberger-vleisbeesrasse. Gevolglik is 227 Bonsmaraen 212 Drakensberger-haarmonsters vanaf onderskeidelik vyf Bonsmara-telers en sewe Drakensberger-telers ontvang vir die identifikasie van die poenageen. Genomiese DNS is geëkstraeer uit die 439 beeshaarmonsters. Die diere is getoets vir hul $\mathrm{P}_{C}$-status met ' $\mathrm{n}$ PCRgebaseerde diagnostiese toets (CELT primer - Allais-Bonnet et al 2013). As gevolg hiervan kan draers van die $\mathrm{P}_{\mathrm{C}-}$ variant geïdentifiseer word en diere as homo- of heterosigotiese poena geïdentifiseer word. PCR-produkte is gevisualiseer op 'n 3\% agarosejel saam met 'n 100bp fragmentleer om die fragmentgrootte van die produkte te bepaal - daar is 'n 202bp verskil tussen $\mathrm{P}_{\mathrm{C}}$ en die wildetipe alleel. Die alleel- en genotipefrekwensies is vir beide rasse bepaal. Op 'n genotipiese vlak was dit moontlik om tussen horing- en homo- en heterosigotiese poenskopdiere te onderskei. Vir die Bonsmara was die frekwensie van waargenome poenadiere 0.714 , waarvan die meerderheid as heterosigotiese poena getoets het $\left(\mathrm{P}_{\mathrm{C}} \mathrm{p}=0.555\right)$. Vir die Drakensberger was die meerderheid diere ook heterosigotiese poena $\left(\mathrm{P}_{\mathrm{C}} \mathrm{p}=0.406\right)$, maar slegs drie homosigotiese poena diere is waargeneem $\left(\mathrm{P}_{C} \mathrm{P}_{C}=0.014\right)$. In beide rasse word 'n relatief hoë frekwensie horingdiere waargeneem (Bonsmara: $\mathrm{pp}=0.286$; Drakensberger: $\mathrm{pp}=0.580$ ). Die diagnostiese DNS-toets is effektief vir die identifisering van hetero- en homosigotiese poenadiere. Met DNS-tegnologie kan die poenastatus van diere vroegtydig geïdentifiseer word, wat die genetiese seleksie van poenadiere sal vergemaklik en versnel. Dit hou ook 'n ekonomiese voordeel vir telers in wanneer gesertifiseerde poenskopbulle bemark kan word. Meer poenskopdiere in die mark het ook voordele vir dierewelsyn deurdat dit metteryd nie meer nodig sal wees om diere te onthoring nie. Die relatief hoë frekwensie van horingdiere wat waargeneem is, bevestig die belangrikheid van 'n DNS-toets, en dat telers eers die poenastatus van diere op 'n genotipiese vlak moet bevestig voordat vermeende poenadiere in 'n paringsprogram ingesluit word. Dit is veral belangrik vir bulle wat vir teeldoeleindes en veilings gebruik gaan word.

Nota: 'n Seleksie van referaatopsommings: Studentesimposium in die Natuurwetenskappe, 25-26 Oktober 2018, SA Akademiegebou, Pretoria, Suid-Afrika. Gasredakteurs: Prof Rudi Pretorius (Departement Geografie, Universiteit van Suid-Afrika); Prof Chris Swanepoel (Departement Besluitkunde, Universiteit van Suid-Afrika); Me Andrea Lombard (Departement Geografie, Universiteit van Suid-Afrika) 


\section{Literatuurverwysings}

Allais-Bonnet, A., Grohs, C., Medugorac, I., Krebs, S., Djari, A., Graf, A., Fritz, S. Seichter, D., Baur, A., Russ, I. \& Bouet, S., 2013, 'Novel insights into the bovine polled phenotype and horn ontogenesis in Bovidae', PloS one, 8, 5, p.e63512.
Grobler, R., Visser, C., Capitan, A. \& Van Marle-Köster, E., 2018, 'Validation of the POLLED Celtic variant in South African Bonsmara and Drakensberger beef cattle breeds', Livestock Science, 217, 136-139. 